Article

\title{
Fuzzy AHP Application for Supporting Contractors' Bidding Decision
}

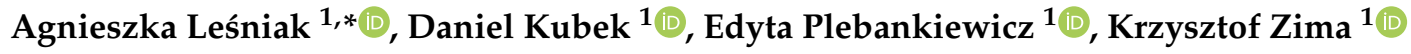 \\ and Stanisław Belniak ${ }^{1}$
}

Cracow University of Technology, Faculty of Civil Engineering, 31-155 Kraków, Poland; dkubek@pk.edu.pl (D.K.); eplebank@L3.pk.edu.pl (E.P.); kzima@L3.pk.edu.pl (K.Z.);

belniaks@ae.krakow.pl (S.B.)

* Correspondence: alesniak@L3.pk.edu.pl; Tel.: +48-12-628-23-30

Received: 14 October 2018; Accepted: 13 November 2018; Published: 16 November 2018

\begin{abstract}
This paper proposes the author's model based on the Fuzzy Analytic Hierarchy Process (FAHP) to improve the efficiency of contractor bidding decisions. The essence of the AHP method is to make pairwise comparisons of available options against all evaluation criteria. The results of these comparisons are recorded in a square matrix in which symmetrical elements are reciprocal. In the expert opinion, a 9-step, bipolar verbal scale was used so that the symmetry of the response was maintained. For contractors from countries where the tendering system is commonly used, the choice of the right tender in which to participate influences their image, financial condition, and their aspiration to succeed. The bid/no bid decision depends on numerous factors associated with the company itself, the environment, and the project concerning the tender. When facing tough competition, contractors search for a solution which increases their chances of winning the tender. The proposed model was based on factors selected by Polish contractors. The original element of the model involves 4 original criteria and 15 sub-criteria for the assessment of investment decision projects to the selection of the most advantageous contract, i.e., the contractor's participation in the bid. For verbal evaluations describing the criteria, symmetric triangular fuzzy numbers were assigned. The authors performed an extended analysis method combined with FAHP in the model. Fuzzy evaluations underwent elaborate analysis, the aim of which was to specify the synthetic priority weights for each criterion. As a result of the application of the method, to prove that the model works, an example from the Polish construction market was presented in which a bid/no bid decision about four possible tenders was to be taken. Despite the considered example applying to Polish conditions, the proposed model can be used also in other countries. The authors' rationale is to produce new and more flexible methodologies in order to realistically model a variety of concrete decision problems.
\end{abstract}

Keywords: bidding decision; Fuzzy Analytic Hierarchy Process (FAHP); contractors; construction industry; decision making

\section{Introduction}

Efforts to gain a construction project include making two vital decisions by the contractor. The first involves deciding whether to bid or not; the second concerns estimating the offer price as accurately as possible, especially the mark-up value that needs to be specified in the bid. An appropriate selection of tenders in which the company wishes to participate plays an important part in establishing its position in the market, and contributes to the contractor's success. Participation in tenders involving projects that do not fit the company's abilities may cause losses. On the other hand, the cancellation of a bid means losing the opportunity to profit, to establish relationships with new customers, and to expand 
the company's business. Yet, bidding and losing the bid causes financial loss and damages reputations. The result of the tender ( $\mathrm{a}$ win or loss) depends on the value of the bid, especially on the mark-up it includes.

Both of the decisions are complex, dynamic, and involve many factors [1]. A bidding decision, despite its being vital for the contractor, often needs to be made quickly and within a limited timeframe. The contractor typically relies on experience, intuition, and subjective information. To facilitate the contractor's reasoning, increase the efficiency of decision making, and limit mistakes and randomness, decision support models are frequently applied.

The article presents the authors' own proposition of a model supporting bidding decisions. The model is based on the Fuzzy Analytic Hierarchy Process (FAHP), facilitating the selection of the most appropriate projects on which to bid. Unlike the classic Analytic Hierarchy Process (AHP), FAHP uses fuzzy logic, which allows a more accurate evaluation of linguistic criteria. A verbal assessment model is presented in the form of a triangular membership function. The model is constructed on the basis of factors influencing a bidding decision identified in Poland. Limit values for the triangular membership function were adopted in such a way that the adopted values corresponded to the values in accordance with a scale from 1-9, as proposed by Saaty, defining the decision-maker's preferences by means of relative assessments of the validity of sub-criteria and variants. The authors of the article distinguished four main evaluation criteria: Company capabilities, Investment characteristics, Financial conditions, and Tender characteristics; these were divided into sub-criteria. In total, 15 project evaluation sub-criteria were obtained. The main aim of this article is to create a decision support model to join the bidding and selection of the best tender from the point of view of the contractor. In order to explain the procedure in the model, a simple calculation example is also shown.

\section{Decision Making Processes in Construction Management}

Decisions taken during the planning and preparation of a development project have a crucial impact on its profitability [2]. The models proposed so far proved to be helpful for the participants of the construction process, i.e., the investors [3,4] and contractors [5-7]. Decisions concerning such problems in most cases belong to multi-criteria issues; therefore, solutions to these issues typically involve various multi-criteria decision making methods. Table 1 summarizes the multi-criteria methods previously used to support decisions concerning the management of a construction project at the pre-investment stage.

Table 1. A summary of example methods used to support decision-making in construction management.

\begin{tabular}{|c|c|c|c|}
\hline Method Name & Aim of Analysis & Number of Criterion Used & Source \\
\hline $\begin{array}{l}\text { Fuzzy AHP; The method of entropy; } \\
\text { Method of criterion impact loss } \\
\text { (CILOS); Integrated Determination of } \\
\text { Objective CRIteria Weights (IDOCRIW) } \\
\text { method; The SAW method; The TOPSIS } \\
\text { method; The COPRAS method }\end{array}$ & $\begin{array}{l}\text { comparing quality } \\
\text { assurance in different } \\
\text { contractor contracts }\end{array}$ & 7 & {$[10]$} \\
\hline The EDAS method & $\begin{array}{l}\text { comparing quality } \\
\text { assurance in different } \\
\text { contractor contracts }\end{array}$ & 7 & {$[11]$} \\
\hline
\end{tabular}


Table 1. Cont.

\begin{tabular}{|c|c|c|c|}
\hline Method Name & Aim of Analysis & Number of Criterion Used & Source \\
\hline $\begin{array}{c}\text { Integration of intuitionistic fuzzy sets } \\
\text { I(FS) theory, ELECTRE and VIKOR } \\
\text { along with Grey Relational } \\
\text { Analysis (GRA) }\end{array}$ & $\begin{array}{l}\text { contractor selection } \\
\text { problem }\end{array}$ & 20 & [13] \\
\hline $\begin{array}{c}\text { Weighted Aggregated Sum Product } \\
\text { Assessment with Grey } \\
\text { Values (WASPAS-G) }\end{array}$ & $\begin{array}{l}\text { evaluating and } \\
\text { selecting contractors }\end{array}$ & 6 & [14] \\
\hline
\end{tabular}

Table 1 reveals that the use of multi-criteria methods in the decision-making processes of business management most frequently concerns the issue of the comparison of quality assurance in various contractor contracts. They include the following methods: fuzzy AHP, entropy, criterion impact loss, SAW, and TOPSIS. Frequently, a multi-criteria analysis is used to support the process of selecting contractors or subcontractors for construction works. The methods used for this purpose encompass AHP, PROMETHEE, Data Envelopment Analysis, ELECTRE, VIKOR, Grey Relational Analysis, and Weighted Aggregated Sum Product Assessment with Grey Values. The study in [15] proposes a hybrid method based on the Weighted Sum Model (WSM) and the Weighted Product Model (WPM). Most of the methods mentioned here are well-known; moreover, as shown by researchers, they may be applied, rendering very good results. Their advantage is that the criteria applied are easy to assess and are understandable for the potential decision maker. What is more, if complex calculations are necessary, their automation is possible. It is worth paying attention to the number of criteria, ranging from 5 to 20 (Table 1), used in analyses. The models mentioned are also applied to bid/no bid decision making processes. There were several early endeavors to develop a model facilitating bidding decisions, one of which was performed by Ahmad [16], who employed the weight model. In the following years, a number of models based on various mathematical devices were created.

One of the more recent models is found in the study by El-Mashaleh [17] presenting a data envelopment analysis (DEA), namely, an efficient non-parametric linear programming method which is applied to benchmarking procedures and selection decision making. DEA uses the contractor's database containing information about previous bidding decisions to create a "best-practice frontier" determined by favorable bidding opportunities. Consequently, the frontier allows us to evaluate new bidding options more efficiently, and to reach a more advantageous bid/no bid decision.

On the other hand, [18] presents an ANFIS model based on a MATLAB software program for processing a set of input data in the way that the human reasoning operates, namely, through neural network learning and fuzzy logic. The results of the analysis proved to be statistically significant.

The study in [19] describes improvements on the existing bid decision-making methods by means of the application of support vector machines and backward elimination regression. In particular, the method helps to attain a parsimonious support vector machine classifier facilitating bid/no bid decision making in offshore oil and gas platform fabrication projects. Then, the output of the support vector machine classifier is compared with other classifiers: the worth evaluation model, linear regression, and neural networks. What the study reveals is the significantly more efficient performance of the support vector machine classifier in comparison with the other methods, thus proving its great explanatory predictive power for bid/no bid decision making. What is more, once the insignificant input variables are removed, the generalization performance of the support vector machines increases. Other attempts to develop an efficient model of bid/no bid decision making include, for example, the fuzzy set theory [20,21], analytic hierarchy process [22,23], game theory [24], multi-criteria analysis methods [25], and artificial neural network [26,27].

In many models, the selection and evaluation of factors influencing the bid/no bid decision occurs prior to the decision making itself, as presented in numerous studies performed in various countries and on a number of markets. Early research concerned the American market in 1988 [28], in which 31 factors were specified. While some of them were found to be very important at the mark-up decision 
stage but not at the bid/no bid decision stage, other factors proved to be significant at both stages. Another study conducted in Saudi Arabia [29] enumerates 37 factors influencing bid/no bid decisions, as identified by the contractors operating in this market. Research conducted in Great Britain [1] helped to establish 55 potential factors influencing contractors' bidding decisions. Considerably fewer were found by Wanous et al. [27], whose formal questionnaire revealed 38 factors that affect the bid/no bid decision, ranked in accordance of their importance to Syrian contractors. On the other hand, the study performed in Saudi Arabia [30] established as many as 87 potential factors, ranked on the basis of 91 responses to the questionnaire. Similar studies, closely resembling those presented in the aforementioned articles, were performed in Palestine [31] and Australia [32]. One of the most recent studies was completed in Poland [33]. The authors proposed 15 factors, being a selection of the factors proposed in literature, and asked 61 contractors to evaluate them. In this way, a ranking list of these factors in order of their importance and frequency of their appearance in the Polish market was created.

Bageis and Fortune [30] found considerable correlations among a number of studies, since the top positions in various rankings were occupied by similar factors. They were not identical, though, as the specifics of the construction markets differ from country to country, so certain factors appeared to be significant in some regions but not in others. The implication is, therefore, that factors influencing $\mathrm{bid} / \mathrm{no}$ bid decisions are conditioned by the particulars of the environment and the market in which the contractor works.

The authors proposed the Fuzzy AHP method to solve the problem of supporting contractors' bidding decisions. Although (as shown above) the classical AHP method, like other multicriteria methods, has already been used by other researchers and presented in the literature, it is difficult to find examples of using Fuzzy AHP to solve the problem of bidding decisions. The authors of the present paper introduced 15 criteria identified by Polish contractors, the number of which does not substantially exceed the size of the set of criteria proposed in multicriteria methods (Table 1). The proposed Fuzzy AHP method provides the expert with the possibility of independently performing evaluations of the opinions of other experts. It allows him/her to freely shape opinions without setting any sharp values. In the decision-making process, objective or subjective opinions or information, both quantitative and qualitative, play a very important role, and with the help of AHP, they can be easily assessed. Any amount of information characterizing the main purpose can be mentioned or even structured in this method. The use of the Fuzzy AHP method improves the way experts deliver opinions, without limiting them to one specific wording or parameter. It therefore increases the possibilities of the application of this method and the flexibility of the solutions obtained thereby.

\section{Bidding Decision Support Systems Based on Fuzzy AHP—Methodology}

The Analytic Hierarchy Process (AHP), developed by Saaty [34], is a method supporting the decision making process. Its aim is to quantify the relative priorities for a particular set of alternatives on a ratio scale on the basis of the decision maker's judgement. The model emphasizes the importance of the decision maker's intuitive judgements, and the consistency with which alternatives are compared in the decision making process [34]. The AHP is combined with other methods or techniques, such as mathematical programming, data envelopment analysis, fuzzy theory, and meta-heuristics [35].

According to bid decisions, most decision makers tend to rely on their knowledge and personal experience, which lead to highly unstructured and uncertain decisions. Although the aim of the AHP is to capture the decision maker's knowledge, the traditional AHP cannot fully reflect the human way of thinking. In the literature, the fuzzy AHP approach is widely used to deal with this inconvenience. The Fuzzy AHP (namely, FAHP) model is based on fuzzy sets theory, in which the membership of the given element is determined by the membership function. Fuzzy decision variable values are described by a membership function which is between zero and one. The membership function defines the degree of truth, that is, the fuzzy decision variable may range between completely true and completely false. This approach is more appropriate when the linguistic variables used are common in the decision process, such as expert judgment. Membership functions may assume various forms: 
trapezoid, Gaussian, or triangular. The method described below involves triangular membership functions, as described in Chang's study [36].

Due to the mentioned characteristics of AHP and fuzzy AHP, these methods are widely used in issues related to decision making regarding various aspects of construction management. AHP and fuzzy AHP were applied, for example, to the ranking and selection of alternatives in construction project management [37], construction projects selection and risk assessment [38], performance evaluation of territorial units [39], and the development of an integrated discounting strategy based on vendors' expectations [40].

In the FAHP method, objects (that is, criteria and alternatives) are evaluated by triangular fuzzy values (TFN). The values of the TFN membership function are $\mu_{M}(x): R \rightarrow[0,1]$, so they generalize the classic Boolean logic. Each triangular fuzzy set is defined unambiguously by three parameters, namely, by triangular fuzzy values $(l, m, u)$ which denote the beginning, middle, and end of the fuzzy triangle, respectively. The value of the membership function $\mu_{M}$ of triangular fuzzy values $M$ in the set $R$ can be specified by the following dependency:

$$
\mu_{M}= \begin{cases}\frac{x}{m-l}-\frac{l}{m-l}, & x \in[l, m] \\ \frac{x}{m-u}-\frac{u}{m-u}, & x \in[m, u] \\ 0, & \text { in other cases }\end{cases}
$$

The function is depicted in Figure 1.

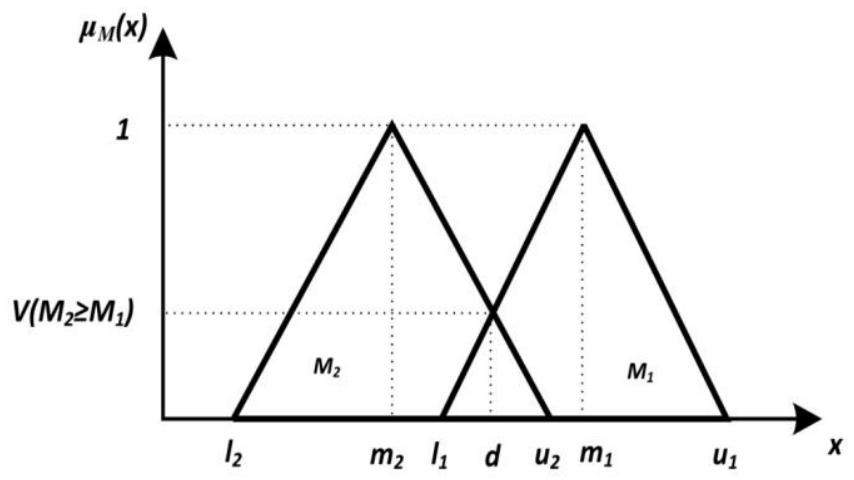

Figure 1. Triangular membership function and intersection between $M_{1}$ and $M_{2}$.

If $l=m=u$, then it is a conventional crisp value, as in the classic AHP.

Table 2 presents example TFN values. In the following part of the article, this scheme was applied to case study calculations.

Table 2. A fuzzy scheme of preference evaluation [41].

\begin{tabular}{ccc}
\hline Qualitative Evaluation & Fuzzy Evaluation & AHP Equivalent \\
\hline Extreme preference & $(2 ; 5 / 2 ; 3)$ & 9 \\
Very strong preference & $(3 / 2 ; 2 ; 5 / 2)$ & 7 \\
Strong preference & $(1 ; 3 / 2 ; 2)$ & 5 \\
Moderate preference & $(1 ; 1 ; 3 / 2)$ & 3 \\
Equal preference & $(1 ; 1 ; 1)$ & 1 \\
Moderate inferiority & $(2 / 3 ; 1 ; 1)$ & $1 / 3$ \\
Strong inferiority & $(1 / 2 ; 2 / 3 ; 1)$ & $1 / 7$ \\
Very strong inferiority & $\left(2 / 5 ; \frac{1}{2} ; 2 / 3\right)$ & $1 / 9$ \\
Extreme inferiority & $(1 / 3 ; 2 / 5 ; 1 / 2)$ & \\
\hline
\end{tabular}

As in the classic AHP method, the analysis should begin by designating a criteria priority matrix and alternatives preference matrix for each criterion. In the fuzzy AHP, this step involves TFN. 
Fuzzy evaluations undergo an extent analysis, the aim of which is to specify the synthetic priority weights. The analysis consists of the following four steps.

Let $X=\left\{x_{1}, x_{2}, \ldots, x_{n}\right\}$ be a set of objects and $U=\left\{u_{1}, u_{2}, \ldots, u_{m}\right\}$ a set of aims. According to this method, each objects has to undergo an extent analysis for each aim of the problem. As a result of such extent analysis, $m$ values for each object will be obtained, which will be represented as follows:

$$
M_{g_{i}}^{1}, M_{g_{i}}^{2}, \ldots, M_{g_{i}}^{m}, i=1,2, \ldots, n
$$

where all $M_{g_{i}}^{j}$ for $j=1,2, \ldots, m$ are triangular fuzzy values.

Step 1: Computation of synthetic fuzzy values for each object of the analysis.

If $M_{g_{i}}^{1}, M_{g_{i}}^{2}, \ldots, M_{g_{i}}^{m}$ are the extent analysis values of the $i$-th object for an $m$-th aim, then the synthetic fuzzy value can be defined as:

$$
S_{i}=\sum_{j=1}^{m} M_{g_{i}}^{j} \odot\left[\sum_{i=1}^{n} \sum_{j=1}^{m} M_{g_{i}}^{j}\right]^{-1}
$$

Since the FAHP uses three values for the evaluation of a particular criterion, it is necessary to define the arithmetic operations involving these values.

If one assumes two TFNs, $M_{1}=\left(l_{1}, m_{1}, u_{1}\right)$ and $M_{2}=\left(l_{2}, m_{2}, u_{2}\right)$, then the operations are as follows:

$$
\begin{gathered}
\left(l_{1}, m_{1}, u_{1}\right) \oplus\left(l_{2}, m_{2}, u_{2}\right)=\left(l_{1}+l_{2}, m_{1}+m_{2}, u_{1}+u_{2}\right) \\
\left(l_{1}, m_{1}, u_{1}\right) \odot\left(l_{2}, m_{2}, u_{2}\right)=\left(l_{1} l_{2}, m_{1} m_{2}, u_{1} u_{2}\right) \\
(\lambda, \lambda, \lambda) \odot\left(l_{2}, m_{2}, u_{2}\right)=\left(\lambda l_{2}, \lambda m_{2}, \lambda u_{2}\right), \text { for } \lambda>0, \lambda \epsilon\left(l_{1}, m_{1}, u_{1}\right)^{-1}=\left(\frac{1}{u_{1}}, \frac{1}{m_{1}}, \frac{1}{l_{1}}\right)
\end{gathered}
$$

Step 2: Comparison of the degree of possibility that $M_{2} \geq M_{1}$.

Another step in the FAHP analysis following the specification of synthetic fuzzy values involves computing the priority vector. To do so, each fuzzy set represented by a synthetic fuzzy value has to be compared with each other. The comparison of two TFNs, $M_{1}=\left(l_{1}, m_{1}, u_{1}\right)$ and $M_{2}=\left(l_{2}, m_{2}, u_{2}\right)$, allows to compute the degree of possibility that $M_{1} \geq M_{2}$ and the degree of possibility that $M_{2} \geq M_{1}$. The degree of possibility $V\left(M_{2} \geq M_{1}\right)$ is expressed by:

$$
V\left(M_{2} \geq M_{1}\right)=\mu(d)= \begin{cases}1, & \text { if } m_{2} \geq m_{1} \\ 0, & \text { if } l_{1} \geq u_{2} \\ \frac{l_{1}-u_{2}}{\left(m_{2}-u_{2}\right)-\left(m_{1}-l_{1}\right)}, & \text { otherwise }\end{cases}
$$

where $d$ is the ordinate of the highest intersection point $D$ between two convex membership functions $\mu_{M_{1}}$ and $\mu_{M_{2}}$.

Step 3: Computation of the smallest degree of possibility $M_{2} \geq M_{1}$.

To compare all the possible fuzzy values $M_{i}=(1,2, \ldots, k)$, one needs to specify the minimum:

$$
V\left(M \geq M_{1}, M_{2}, \ldots, M_{k}\right)=\min V\left(M \geq M_{i}\right), i=1,2, \ldots, k
$$

Step four involves calculating the priority weight vector for variants. Let us assume that:

$$
d^{\prime}\left(A_{i}\right)=\min V\left(S_{i} \geq S_{k}\right) \text { for } k=1,2, \ldots, n, i k \neq I
$$


The weight vector for variants is represented as:

$$
W^{\prime}=\left(d^{\prime}\left(A_{1}\right), d^{\prime}\left(A_{2}\right), \ldots, d^{\prime}\left(A_{n}\right)\right)^{T}
$$

To calculate the priority weight vector for individual variants, one needs to normalize vector $W^{\prime}$, which gives vector $W$ :

$$
W=\left(d\left(A_{1}\right), d\left(A_{2}\right), \ldots, d\left(A_{n}\right)\right)^{T}
$$

where $W$ is a vector of crisp numbers.

This procedure of computing normalized priority weights should be applied to the evaluation of particular alternatives of each criterion (alternatives preference matrices). The particular steps of the FAHP and the steps of the procedure of calculating weight vectors are presented in Figure 2 (based on [37]). The final ranking can be obtained by a sum of products of particular criteria weights and weights of particular alternatives, as in the AHP method.

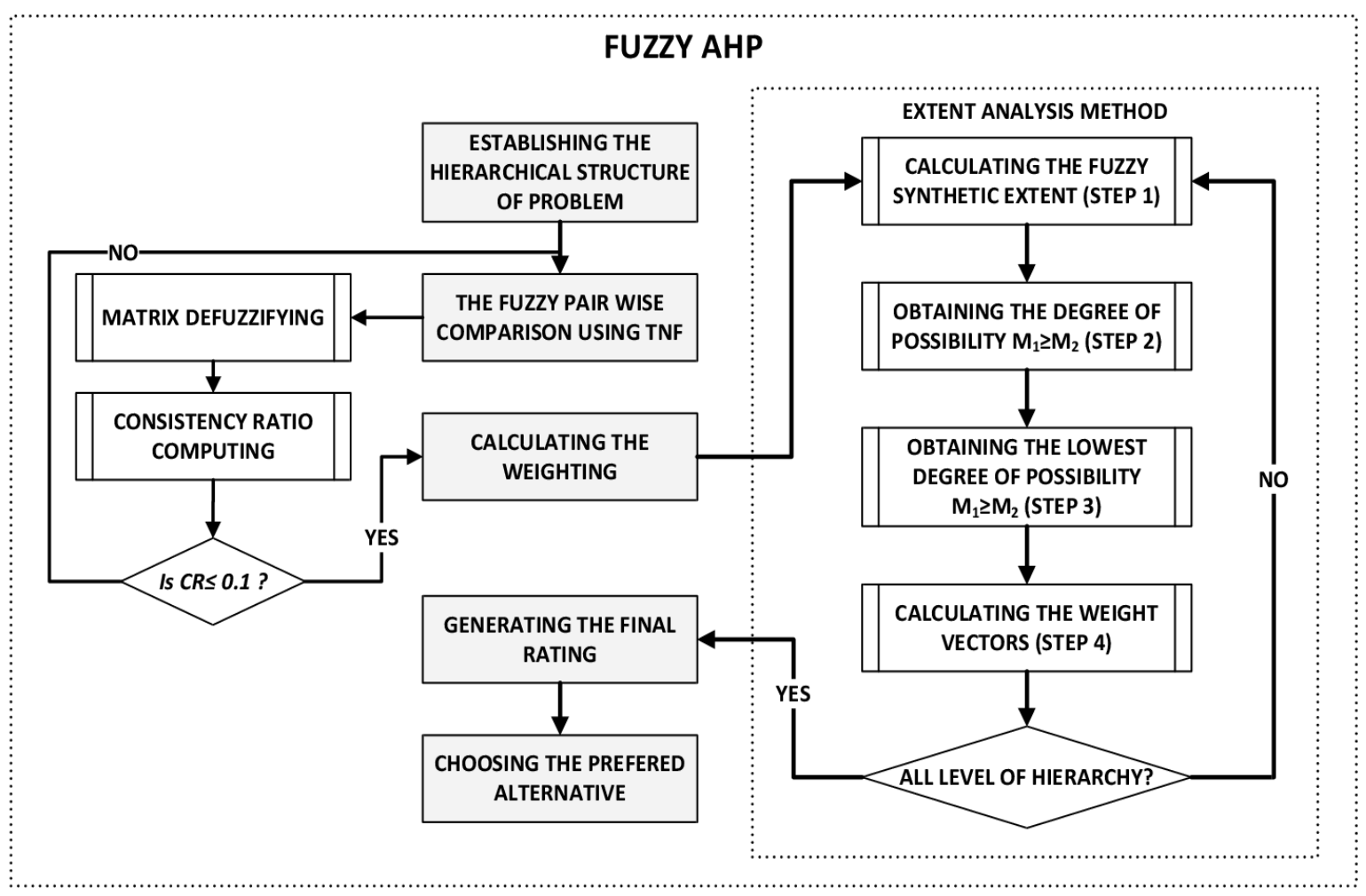

Figure 2. Fuzzy analytic hierarchy process flow chart.

An essential step in both the AHP and FAHP methodologies is checking the consistency ratio of the pairwise comparison matrix. In the classical approach, the consistency ratio (CR) is estimated on a consistency index $(\mathrm{CI})$ of the comparison matrix and a random-like matrix (RI), which simulates highly inconsistent judgments in the comparison stage. Saaty [34] has shown that a CR of 0.10 or less is acceptable to continue the AHP analysis. In FAHP, the consistency ratio procedure is preceded by defuzzifying the pairwise comparison matrix. In the presented approach, the graded mean integration approach is utilized. It is assumed that $\operatorname{TFN} M=(l, m, u)$ is transformed into a crisp number by formula:

$$
P(M)=\frac{l+4 m+u}{6}
$$

After the defuzzification of each pairwise comparison matrix, the Saaty's consistency is applied. 


\section{Project Selection for Bidding-Model Application}

The FAHP method presented above was applied to the selection of the most advantageous contract, which indicates the contractor's participation in the bid. As previous research have observed, the evaluation of any complex object by human beings grows in complexity as they try to describe the object precisely, to the point where the evaluation becomes imprecise. Moreover, in [42], the authors revealed that a one-stage decision problem structure with multiple criteria may lead to the elimination of less significant criteria when the FAHP is used. Therefore, the decision problem was constructed as a two-stage one; criteria were classified into main criteria with sets of sub-criteria assigned to them. Due to such division, the evaluation of particular ventures was easier for the experts.

The FAHP model was proposed only for contractors because they decide about participating in the tender and performing actions aimed at the preparation of the offer without being sure of winning. The authors do not consider the result of the tender in the model, nor the way it is organized, but only participation in it. The model serves to support solely the contractor's decisions about choosing the most suitable tender to join from a number of various projects. Opinions of other participants do not affect the decision.

The example considered concerns Polish conditions, where the tender procedure is the most popular system for awarding construction works contracts. In 2014-2017, the tender was used in over $80 \%$ of all contracts awarded for construction work in the Polish public sector [43]. The interest of contractors in tenders for construction works is considerable, which is proven by the fact that, according to the Public Procurement Bulletin [43], for 45\% of tenders announced in 2017, three or more offers were submitted. Polish contractors are often faced with the choice of which tender to participate and engage resources in before preparing the offer. Therefore, research was undertaken among Polish contractors regarding the factors influencing the decision to participate in the tender, which were presented in [44].

Polish contractors (61 out of 160) responded to the questionnaire, which made up 38\%. Among the respondents, $38 \%$ of companies signed more than $75 \%$ of contracts resulting from bidding, while $19 \%$ of respondents signed no more than $25 \%$. They were asked to specify the degree of importance of the 15 proposed factors, marking them on a 1-7 scale, where 1 was the factor with no influence on the decision and 7 was the one with the greatest significance in decision making. For each factor, an average score was established. On the basis of these data, 15 factors were selected which were then grouped into four main criteria, i.e., C1 (Company's capabilities), C2 (Investment characteristics), C3 (Financial conditions), and C4 (Tender characteristics) influencing the bidding decision. Subsequently, sets with sub-criteria were assigned to the main ones. Table 3 presents factor groups (criteria) deciding about the selection of a project and their average evaluations.

The contractor is considering a participation in one of the four potential tenders. Each of them concerns a different project: P1, P2, P3 and P4. Figure 3 presents the hierarchical structure of the model in which "Project selection for bidding" serves as the target hierarchy at the highest level, the influence factors function as criteria hierarchy at the intermediate levels, and alternatives constitute an alternatives hierarchy at the lowest level.

The projects P1, P2, P3 and P4 were evaluated by two experts-employees of one of the Polish construction companies invited to participate in these studies. The experts were the manager and the deputy head of the tender preparation department, whose professional experience amounted to more than 15 years. They were obliged by the company to make a decision about participating in one of 4 tenders (respectively for project: P1, P2, P3 and P4). The evaluation of the projects was made during the meeting of experts and the co-authors of the paper. The evaluation of the four projects in accordance with the sub-criteria adopted (on a 1-7 scale) is presented in Table 4. 
Table 3. Average evaluation of the criteria involved in the decision process of selecting a project.

\begin{tabular}{ccc}
\hline Criterion/Sub-Criterion & Name of the Criterion/Factor & $\begin{array}{c}\text { Average Evaluation of } \\
\text { Criterion/Factor * }\end{array}$ \\
\hline C1 & Company's capabilities & 5.14 \\
\hline C1_1 & Need of work & 5.21 \\
C1_2 & Past experience with similar projects & 5.95 \\
C1_3 & Location of the project & 4.25 \\
\hline C2 & Investment characteristics & 4.48 \\
\hline C2_1 & Size of the project (e.g., cubic measure) & 4.95 \\
C2_2 & Time of project duration & 4.49 \\
C2_3 & Type of works & 5.98 \\
C2_4 & Degree of works complexity & 3.25 \\
C2_5 & Necessity for specialized equipment & 3.51 \\
C2_6 & Possible subcontractors & 3.87 \\
C2_7 & Owner's reputation & 5.31 \\
\hline C3 & Financial conditions & 5.35 \\
\hline C3_1 & Value of the project & 5.30 \\
C3_2 & Contract conditions & 5.89 \\
C3_3 & Profits from similar past projects & 4.87 \\
\hline C4 & Tender characteristics & 4.14 \\
\hline C4_1 & Time for the preparation of the bid & 3.89 \\
C4_2 & Criteria of bid selection & 4.38 \\
\hline
\end{tabular}

${ }^{*}$ According to research by [21].

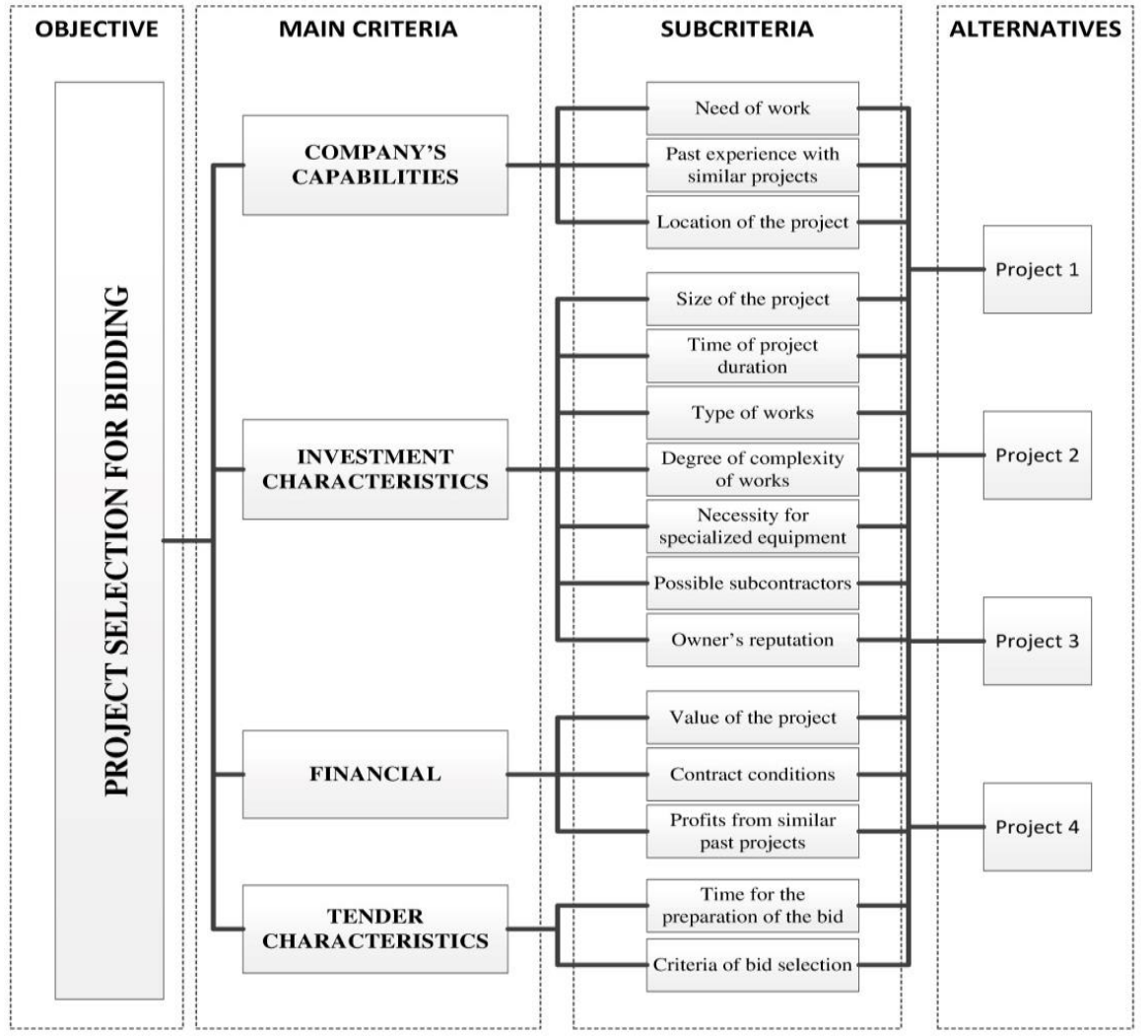

Figure 3. The hierarchy of the AHP model for tender selection. 
Table 4. Evaluation of the four ventures under discussion.

\begin{tabular}{ccccc}
\hline \multirow{2}{*}{ Sub-Criterion/Factor } & \multicolumn{4}{c}{ Project } \\
\cline { 2 - 5 } & P1 & P2 & P3 & P4 \\
\hline C1_1 & 7 & 5 & 7 & 5 \\
C1_2 & 4 & 7 & 7 & 7 \\
C1_3 & 4 & 5 & 6 & 6 \\
C2_1 & 3 & 3 & 5 & 2 \\
C2_2 & 3 & 4 & 6 & 5 \\
C2_3 & 5 & 7 & 7 & 6 \\
C2_4 & 4 & 6 & 7 & 7 \\
C2_5 & 4 & 6 & 6 & 6 \\
C2_6 & 6 & 6 & 6 & 3 \\
C2_7 & 6 & 4 & 7 & 4 \\
C3_1 & 4 & 3 & 4 & 2 \\
C3_2 & 5 & 4 & 6 & 4 \\
C3_3 & 4 & 4 & 5 & 4 \\
C4_1 & 6 & 5 & 7 & 6 \\
C4_2 & 4 & 5 & 4 & 4 \\
\hline
\end{tabular}

Since the judgment scale in the FAHP involves nine relative ranks, each evaluation presented in the research was transformed into the respective FAHP ranks. For this purpose, a simple method was utilized. To determine the relative rank of $i$-th and $j$-th objects, the difference between the obtained evaluation was counted. Afterward, a new threshold is computed, based on the range between absolute judgment obtained in the research and on a number of FAHP ranks. In the next step, in comparing object $i$-th and object $j$-th, the absolute value of the difference is used to directly search for the appropriate Saaty rank (the absolute value of the difference is compared with the newly-evaluated threshold).

While computing all the steps of the FAHP, one can obtain synthetic values of fuzzy triangles for the evaluation of the decision problem objects. Figure 4 illustrates an example of such an evaluation with synthetic TFN values for the main criteria (the consistency ratio for given example equals $\mathrm{CR}=0.0043$, which proves the consistency of comparison judgments).

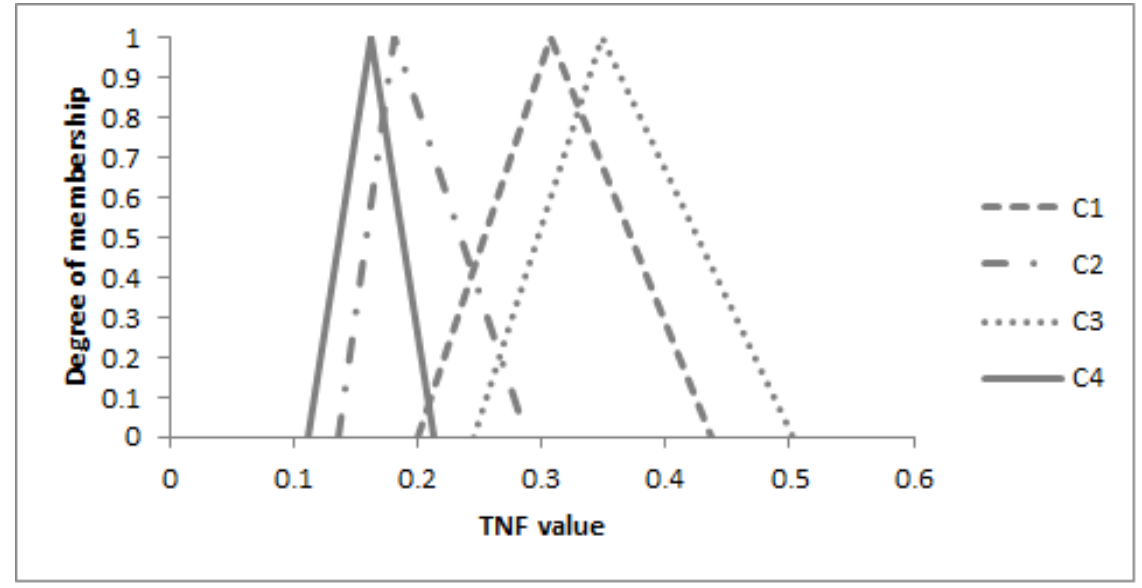

Figure 4. Synthetic TFN values for main criteria.

The characteristic feature of the FAHP analysis is the capability to obtain sets of fuzzy values of individual objects which are then analysed by TFN. This feature is similar to human reasoning.

Criterion C3: Financial condition received the experts' highest rating $(5,35)$, so the synthetic TFN are the highest. The triangle in Figure 4 is the widest and the most right-oriented. This result is highly reliable. In addition, it shares a part with TFN for criterion C1 (company's capabilities) and C2 
(Investment characteristics), which indicates a degree of superiority of one criterion over the other. A greater common set indicates a greater criteria equivalence. The lack of a set in common means large dominance of one over the other, as in the case of criterion C3 (financial conditions) and C4 (tender characteristics).

Table 5 presents the results obtained by the FAHP method—normalized priority weight vectors for each individual project.

Table 5. Normalized priority weight vectors for projects.

\begin{tabular}{lcccccc}
\hline \multirow{2}{*}{ Names } & \multicolumn{5}{c}{ Priority Weight Vector for Each Individual Project } \\
\cline { 2 - 6 } & Criteria & Sub-Criteria & P1 & P2 & P3 & P4 \\
\hline C1_1 & \multirow{2}{*}{0.4045} & 0.3381 & 0.5000 & 0.0000 & 0.5000 & 0.0000 \\
C1_2 & 0.6619 & 0.0000 & 0.3333 & 0.3333 & 0.3333 \\
C1_3 & & 0.0000 & 0.0309 & 0.2253 & 0.3719 & 0.3719 \\
\hline C2_1 & & 0.1990 & 0.0264 & 0.0264 & 0.9472 & 0.0000 \\
C2_2 & & 0.1287 & 0.0000 & 0.1086 & 0.5586 & 0.3329 \\
C2_3 & \multirow{2}{*}{0.1026} & 0.3544 & 0.0309 & 0.3719 & 0.3719 & 0.2253 \\
C2_4 & 0.0000 & 0.0000 & 0.1870 & 0.4065 & 0.4065 \\
C2_5 & & 0.0028 & 0.0000 & 0.3333 & 0.3333 & 0.3333 \\
C2_6 & & 0.0547 & 0.3333 & 0.3333 & 0.3333 & 0.0000 \\
C2_7 & & 0.2603 & 0.3119 & 0.0000 & 0.6881 & 0.0000 \\
\hline C3_1 & \multirow{5}{*}{0.4928} & 0.2692 & 0.3719 & 0.2253 & 0.3719 & 0.0309 \\
C3_2 & 0.7308 & 0.3694 & 0.0333 & 0.5640 & 0.0333 \\
C3_3 & & 0.0000 & 0.1688 & 0.1688 & 0.4937 & 0.1688 \\
\hline C4_1 & \multirow{2}{*}{0.0000} & 0.0000 & 0.2474 & 0.0809 & 0.4244 & 0.2474 \\
C4_2 & & 1.0000 & 0.1688 & 0.4937 & 0.1688 & 0.1688 \\
\hline & & Solution & 0.2627 & 0.1486 & 0.4707 & 0.1180 \\
\hline
\end{tabular}

The most advantageous venture, as the method proved, is P3, which received the highest priority weight, i.e., 0.4707. Interestingly enough, the fourth criterion C4 (tender characteristics), which involved such factors as bid preparation time and the client's selection criteria, was not considered to be important by the decision makers. It is likely that the contractor's experience makes it possible to prepare a bid on time, as required by the client, or the preparation time is sufficient in practice.

The basic tool in the selection of the most advantageous offer for construction work in Poland is the accepted criteria for the evaluation of offers. Usually, the procuring entities do not apply more than 3 criteria, of which the most important weight is always assigned to the price criterion when evaluating the best offer [43]. Therefore, the type of the criteria used are not as vital from the point of view of the contractor. Additionally, FAHP eliminated some sub-criteria, namely: C1_3: location of the project, C2_4: degree of works complexity, C3_3: profits from similar past projects and C4_1: time for the preparation of the bid. The normalized priority weights for these sub-criteria equal zero. Each of the eliminated sub-criteria belongs to a different main criteria group. The location of the project (C1_3) and the degree of work's complexity (C2_4) are vital for the calculation of the investment costs, yet, they are irrelevant for the analysed bid/no bid decision case. Profits from similar past projects (C3_3) is the factor which, in surveys mentioned above [14], was placed 9th out of 15. Thus, it was not rated as particularly vital, and in the case under consideration, as rather immaterial too, which proves how individual and unique in character each construction project is.

\section{Conclusions}

Tendering is an obligatory and basic process (though not the only one) on the construction market in the Polish public sector. In 2017, the majority of construction orders resulted from bids, (according to the Public Procurement Bulletin [42], 86\% of orders). This way of acquiring contractors is also used by clients representing the private sector, who themselves decide on the form of awarding contracts. 
A tender has many advantages, as it is the most competitive process, while its procedure is not complicated. Polish contractors identified 15 factors influencing their bidding decisions. These factors were grouped into main criteria, with each group consisting of sets with sub-criteria. On this basis, a model was proposed, the aim of which was to facilitate the choice of a tender appropriate for the company. To construct the model, the Fuzzy AHP method was used. To prove that the model works, an example was presented in which a bid/no bid decision about four possible tenders was to be taken. As a result of the application of the method, the P3 project was shown to be the one with the highest priority weight (0.4707). It is noteworthy that, according to experts, the modelling performance proved that the most significant element of evaluation was the criterion concerning the financial conditions of the project under tender, while the least vital one was the specifications of the tender itself, namely, the time of bid preparation and the criteria of bid selection. The model proposed here is assumed to be universal, and may be applied to facilitate contractor bidding decisions not only on the Polish market. However, the type and influence of the factors on bidding decisions should be related to the environment in which the contractor works. In further studies, the authors plan to focus on further objectivization of the selected criteria for assessing the problem under investigation, as well as their validity. Attempts will also be made to analyze the flexibility of the final decision, by using sensitivity analyses, and measuring the consistency of assessments made by the decision-maker.

Author Contributions: The individual contribution and responsibilities of the authors were as follows: A.L. and E.P. made a review of the literature concerning models supporting bidding decisions and distinguished in the study factors influencing bid/no bid decisions. A.L designed the research main idea and collected the data. D.K. and K.Z. together analyzed the data and the obtained results. S.B. provided extensive advice throughout the study results and methodology. All the authors have read and approved the final manuscript.

Funding: This research received no external funding.

Conflicts of Interest: The authors declare no conflict of interest.

\section{References}

1. Shash, A.A. Factors considered in tendering decisions by top UK contractors. Constr. Manag. Econ. 1993, 11, 111-118. [CrossRef]

2. Gajzler, M.; Zima, K. Evaluation of Planned Construction Projects Using Fuzzy Logic. Int. J. Civ. Eng. 2017, 15, 641-652. [CrossRef]

3. Plebankiewicz, E. Modelling decision-making processes in bidding procedures with the use of the fuzzy sets theory. Int. J. Strateg. Prop. Manag. 2014, 18, 307-316. [CrossRef]

4. Zima, K. The concept of investment decision support model using fuzzy set theory. In Proceedings of the 11th International Conference of Numerical Analysis and Applied Mathematics 2013 (ICNAAM 2013), Rhodes, Greece, 21-27 September 2013; pp. 1307-1311.

5. Plebankiewicz, E.; Leśniak, A. Overhead costs and profit calculation by polish contractors. Technol. Econ. Dev. Econ. 2013, 19, 141-161. [CrossRef]

6. Zavadskas, E.K.; Antuchevičienè, J.; Kapliński, O. Multi-criteria decision making in civil engineering: Part I-A state-of-the-art survey. Eng. Struct. Technol. 2015, 7, 103-113. [CrossRef]

7. Hoła, B. Identification and evaluation of processes in a construction enterprise. Arch. Civ. Mech. Eng. 2015, 15, 419-426. [CrossRef]

8. Gul, P. Subcontractor selection using the integration of the AHP and PROMETHEE methods. J. Civ. Eng. Manag. 2016, 22, 1042-1054. [CrossRef]

9. Yang, J.-B.; Wang, H.-H.; Wang, W.-C.; Ma, S.-M. Using data envelopment analysis to support best-value contractor selection. J. Civ. Eng. Manag. 2016, 22, 199-209. [CrossRef]

10. Trinkūnienè, E.; Podvezko, V.; Zavadskas, E.K.; Jokšienè, I.; Vinogradova, I.; Trinkūnas, V. Evaluation of quality assurance in contractor contracts by multi-attribute decision-making methods. Econ. Res.-Ekon. Istraž. 2017, 30, 1152-1180. [CrossRef]

11. Keshavarz-Ghorabaee, M.; Amiri, M.; Zavadskas, E.K.; Turskis, Z.; Antucheviciene, J. A Dynamic Fuzzy Approach Based on the EDAS Method for Multi-Criteria Subcontractor Evaluation. Information 2018, 9, 68. [CrossRef] 
12. Khanzadi, M.; Turskis, Z.; Amiri, G.G.; Chalekaee, A. A model of discrete zero-sum two-person matrix games with grey numbers to solve dispute resolution problems in construction. J. Civ. Eng. Manag. 2017, 23, 824-835. [CrossRef]

13. Hashemi, H.; Mousavi, S.M.; Zavadskas, E.K.; Chalekaee, A.; Turskis, Z. A New Group Decision Model Based on Grey-Intuitionistic Fuzzy-ELECTRE and VIKOR for Contractor Assessment Problem. Sustainability 2018, 10, 1635. [CrossRef]

14. Zavadskas, E.K.; Turskis, Z.; Antucheviciene, J. Selecting a Contractor by Using a Novel Method for Multiple Attribute Analysis: Weighted Aggregated Sum Product Assessment with Grey Values (WASPAS-G). Stud. Inform. Control 2015, 24, 141-150. [CrossRef]

15. Zavadskas, E.K.; Turskis, Z.; Antucheviciene, J.; Zakarevicius, A. Optimization of Weighted Aggregated Sum Product Assessment. Electron. Electr. Eng. 2012, 122, 3-6. [CrossRef]

16. Ahmad, I. Decision-support system for modeling bid/no-bid decision problem. J. Constr. Eng. Manag. 1990, 116, 595-608. [CrossRef]

17. El-Mashaleh, M.S. Empirical framework for making the bid/no-bid decision. J. Manag. Eng. 2013, 29, 200-205. [CrossRef]

18. Polat, G.; Bingol, B.N.; Uysalol, E. Modeling Bid/No Bid Decision Using Adaptive Neuro Fuzzy Inference System (ANFIS): A Case Study. In Proceedings of the 2014 Construction Research Congress: Construction in a Global Network, Atlanta, GA, USA, 19-21 May 2014; pp. 1083-1092.

19. Sonmez, R.; Sözgen, B. A support vector machine method for bid/no bid decision making. J. Civ. Eng. Manag. 2017, 23, 641-649. [CrossRef]

20. Cheng, M.-Y.; Hsiang, C.-C.; Tsai, H.-C.; Do, H.-L. Bidding decision making for construction company using a multi-criteria prospect model. J. Civ. Eng. Manag. 2011, 17, 424-436. [CrossRef]

21. Leśniak, A.; Plebankiewicz, E. Modeling the Decision-Making Process Concerning Participation in Construction Bidding. J. Manag. Eng. 2015, 31. [CrossRef]

22. Chou, J.S.; Pham, A.D.; Wang, H. Bidding strategy to support decision-making by integrating fuzzy AHP and regression-based simulation. Autom. Constr. 2013, 35, 517-527. [CrossRef]

23. Leśniak, A. The simplified bidding decision model based on AHP method in ordering of investor's supervision service. In Proceedings of the 14th GeoConference on Ecology, Economics, Education and Legislation, Multilateral Relations and Funding Opportunities, Albena, Bulgaria, 17-26 June 2014; Volume 3, pp. 501-508.

24. Liu, J.B.; Hong, R.; Guo, X.J. Study on the Game Mechanism of Construction Project Bidding. In Proceedings of the International Joint Conference on Artificial Intelligence, Pasadena, CA, USA, 11-17 July 2009; pp. 814-817.

25. Leśniak, A.; Radziejowska, A. Supporting bidding decision using multi-criteria analysis methods. Procedia Eng. 2017, 208, 76-81. [CrossRef]

26. Leśniak, A. Supporting contractors' bidding decision: RBF neural network application. In Proceedings of the International Conference on Numerical Analysis and Applied Mathematics (ICNAAM-2015), Rhodes, Greece, 23-29 September 2015; Volume 1738.

27. Wanous, M.; Boussabaine, A.H.; Lewis, J. A neural network bid/no bid model, the case for contractors in Syria. Constr. Manag. Econ. 2003, 21, 737-744. [CrossRef]

28. Ahmad, I.; Minkarah, I. Questionnaire survey on bidding in construction. J. Manag. Eng. Div. 1988, 4, 229-243. [CrossRef]

29. Shash, A.A.; Abdul-Hadi, N.H. Factors affecting a contractor's mark-up size decision in Saudi Arabia. Constr. Manag. Econ. 1992, 10, 415-429. [CrossRef]

30. Bageis, A.S.; Fortune, C. Factors affecting the bid/no bid decision in the Saudi Arabian construction contractors. Constr. Manag. Econ. 2009, 27, 53-71. [CrossRef]

31. Enshassi, A.; Mohamed, S.; El Karriri, A. Factors affecting the bid/no bid decision in the Palestinian construction industry. J. Financ. Manag. Prop. Constr. 2010, 15, 118-142. [CrossRef]

32. Shokri-Ghasabeh, M.; Chileshe, N. Critical factors influencing the bid/no bid decision in the Australian construction industry. Constr. Innov. 2016, 16, 127-157. [CrossRef]

33. Leśniak, A. Classification of the Bid/No Bid Criteria-Factor Analysis. Arch. Civ. Eng. 2015, 61, 79-90. [CrossRef]

34. Saaty, T.L. The Analytic Hierarchy Process; McGraw-Hill: New York, NY, USA, 1980. 
35. Ho, W. Integrated analytic hierarchy process and its applications-A literature review. Eur. J. Oper. Res. 2008, 186, 211-228. [CrossRef]

36. Chang, D. Application of extent analysis method on fuzzy AHP. Eur. J. Oper. Res. 1996, 95, 649-655. [CrossRef]

37. Prascevic, N.; Prascevic, Z. Application of fuzzy AHP for ranking and selection of alternatives in construction project management. J. Civ. Eng. Manag. 2017, 23, 1123-1135. [CrossRef]

38. Taylana, O.; Bafail, A.O.; Abdulaala, R.M.S. Construction projects selection and risk assessment by fuzzy AHP and fuzzy TOPSIS methodologies. Appl. Soft Comput. 2014, 17, 105-116. [CrossRef]

39. Çalik, A.; Yapici Pehlivan, N.; Kahraman, C. An integrated fuzzy AHP/DEA approach for performance evaluation of territorial units in Turkey. Technol. Econ. Dev. Econ. 2018, 24, 1280-1302. [CrossRef]

40. Ucal Sari, I. Development of an integrated discounting strategy based on vendors' expectations using FAHP and FUZZY goal programming. Technol. Econ. Dev. Econ. 2018, 24, 635-652. [CrossRef]

41. Kutlu, A. Fuzzy failure modes and effects analysis by fuzzy TOPSIS-based fuzzy AHP. Experts Syst. Appl. 2012, 39, 61-67. [CrossRef]

42. Plebankiewicz, E.; Kubek, D. Multicriteria selection of the building material supplier using AHP and fuzzy AHP. J. Constr. Eng. Manag. 2015, 142, 40-57. [CrossRef]

43. Report of the Public Procurement Office on the Functioning of the Public Procurement System in 2017. Available online: https://www.uzp.gov.pl/baza-wiedzy/analizy-systemowe/sprawozdania-ofunkcjonowaniu-systemu-zamowien-publicznych (accessed on 26 October 2018).

44. Plebankiewicz, E.; Kozik, R. The transformation of the tender evaluation process in public procurement in Poland. IOP Conf. Ser. Mater. Sci. Eng. 2017, 251, 012042. [CrossRef]

(C) 2018 by the authors. Licensee MDPI, Basel, Switzerland. This article is an open access article distributed under the terms and conditions of the Creative Commons Attribution (CC BY) license (http:/ / creativecommons.org/licenses/by/4.0/). 